\title{
The Crisis of Multiculturalism in Modern Germany
}

\section{La crisis del multiculturalismo en la Alemania moderna}

\author{
Marat Zufarovich Galiullin \\ Kazan (Volga Region) Federal University, Kazan, Russia \\ ORCID ID: 0000-0002-3798-4328 \\ Viktor Evgenievich Tumanin \\ Kazan (Volga Region) Federal University, Kazan, Russia \\ ORCID ID: 0000-0002-9260-3217 \\ Ildar Kimovich Kalimonov \\ Kazan (Volga Region) Federal University, Kazan, Russia \\ ORCID ID: 0000-0001-6322-2426 \\ Elvira Imbelevna Kamaletdinova \\ Kazan (Volga Region) Federal University, Kazan, Russia \\ ORCID ID: 0000-0003-3619-6335 \\ Zakhar Vasilievich Pokudov \\ Kazan (Volga Region) Federal University, Kazan, Russia \\ ORCID ID: 0000-0002-4282-7132
}

Received 09-08-20 Revised 10-10-20

* Correspondence

Email: maratscorpion@yandex.com
Accepted 20-12-21 On line 03-01-21

\section{Citation:}




\begin{abstract}
Migration is one of the main factors, which is creating the modern world, with more than 60 million displaced people. The twenty-first century is a migrant century, since global mobility is a highly stratified phenomenon, ranging from a simple tourist to an illegal worker; Or as a "product" of traffickers to refugee status forced to leave their origin country because of climate change, poverty or wars. Thus, (forced) migration contributes to changes in the structures and institutions of global political, economic and social relations. Nowadays two major demographic trends in the European Union are: continuous population ageing and increasing of migration flows. The abolition of internal borders within the EU has contributed to the spread of concerns caused by security shortages and new challenges, leading to strengthen politicization and securitization of migration and granting shelter. There have been recent discussions in Germany about immigration, integration and multiculturalism. German Chancellor Angela Merkel acknowledged the crisis of Germany 's multiculturalism system. She also said efforts by the US and UK to promote diversity had only led to a weakening of national identity and increased extremist voices in immigrant communities. It is believed, that multiculturalism seems to have come its way. The multiculturalism has been criticized by the European Union. Criticism of far-right diversity management strategy has become a major part of European politics. In addition, from Scandinavian countries to Greece, anti-immigration parties and the number of votes has increased among the population concerned about the effects of growing diversity.
\end{abstract}

Keywords: foreign regional studies, history, international relations, multiculturalism, Germany.

\title{
Resumen
}

La migración es uno de los principales factores que está creando el mundo moderno, con más de 60 millones de personas desplazadas. El siglo XXI es un siglo de migrantes, ya que la movilidad global es un fenómeno altamente estratificado, que va desde un simple turista hasta un trabajador ilegal; O como un "producto" de los traficantes a la condición de refugiados obligados a abandonar su país de origen debido al cambio climático, la pobreza o las guerras. Así, la migración (forzada) contribuye a cambios en las estructuras e instituciones de las relaciones políticas, económicas y sociales globales. Hoy en día, dos grandes tendencias demográficas en la Unión Europea son: el envejecimiento continuo de la población y el aumento de los flujos migratorios. La abolición de las fronteras internas dentro de la UE ha contribuido a la propagación de preocupaciones causadas por la escasez de seguridad y los nuevos desafíos, lo que ha llevado a fortalecer la politización y la titulización de la migración y la concesión de refugio. Ha habido discusiones recientes en Alemania sobre inmigración, integración y multiculturalismo. La canciller alemana, Angela Merkel, reconoció la crisis del sistema multicultural de Alemania. También dijo que los esfuerzos de EE. UU. Y el Reino Unido para promover la diversidad solo han llevado a un debilitamiento de la identidad nacional y al aumento de voces extremistas en las comunidades de inmigrantes. Se cree que el multiculturalismo parece haber llegado. El multiculturalismo ha sido criticado por la Unión Europea. Las críticas a la estrategia de gestión de la diversidad de extrema derecha se han convertido en una parte importante de la política europea. Además, desde los países escandinavos hasta Grecia, los partidos antiinmigrantes y el número de votos ha aumentado entre la población preocupada por los efectos de la creciente diversidad.

Palabras clave: estudios regionales extranjeros, historia, relaciones internacionales, multiculturalismo, Alemania.

\section{Introduction}

Over the past few decades, especially in recent years, many countries in Europe have seen a significant rise in the number of immigrants. "Throughout the 20th century, immigration in Western Europe increased due to labour needs, economic inequality between European countries, decolonization outside Europe, and growing up of refugees." 
The collapse of the Soviet Union, as well as the collapse of Yugoslavia, led to the migration of millions of asylum-seekers in western Europe. By the end of the 20th century, most EU countries felt the growth in the number of immigrants: for example, "Spain has three times, where approximately 31\% of immigrants from Latin America" (Hierro, 2013), "Italy has four times between 1980 and 1997" (Novotný, 2015).

Overall, in the European Union, this exponential growth in immigrant numbers continued in the 21st century. In 2012, migrants in the EU accounted for approximately $4.1 \%$ of the population, or about 20.7 million people. 'Of these, 38.5\% of immigrants were from non-EU countries, including 24.5\% from Africa, 22\% from Asia, 14.2\% from America and $0.8 \%$ from Oceania. As of 2011, about $9.4 \%$ of the world 's 214 million migrants were third-country nationals living in the EU, with the largest national groups from Turkey, Morocco and Albania. There are 15 to 20 million Muslims living in EU member states who have arrived in the EU mainly as a result of these migration processes" (Archick et al., 2012)

"In 1950, the amount of foreign migrants in Germany was approximately $1 \%$ of the population." (Migration and Integration: Residence law and policy on migration and integration in Germany, 2011) Since then, the number of immigrants has enhanced significantly. Most of the foreign population growth was made up of "gastarbeiters" arriving between 1955 and 1973, and asylum seekers began arriving in large quantities in 1980. Eventually, the oil crisis in the early 1970s, recession, and labor market crisis ended the gastarbeiter program and recruitment. Although the government intended to reduce the number of foreigners in Germany, many of those have already decided to stay in the country to maintain their residency status. To do this, they brought their families to Germany. At that time, the German government tried to encourage return to host countries by paying thousands of DM to gastarbeiters. However, only a small amount of those who were going home anyway were taking money.

While immigration is on the rise in Europe, integration efforts are struggling to keep up. "European national governments have the primary responsibility to create and enforce integration rules. The European Commission plays an important role in setting better benchmarks in EU member states. The Commission also coordinates and monitors integration policy standards among member States and acts as a forum for member States implementing joint strategies and common objectives" (Nesterova, 2012).

\section{Methods}

The statement of the material was based on a systematic approach, which involves a comprehensive analysis of both horizontal and vertical linkages of the system for the entry and adaptation of immigrants into the EU.

The use of a relatively historical method in this case makes it possible to determine the effectiveness of policy decisions at certain stages of Germany 's development regarding to migrants within the framework of a pragmatic approach to the study of social processes.

The historical and genetic method in this case creates an opportunity to trace the general course of events. This method helped to identify a change in the direction of the policy of the German Governments towards migrants at the turn of the century.

In general, the analysis based on the principles of philosophical hermeneutics of the 20th century was the basis for studying the problem of migrants, which requires considering of all events and phenomena in the context of the relevant era, when the assessment of events is given in terms of a specific historical situation. This method is applicable comprehensively, as it allows to explain not only the influence on social processes of objective factors of historical development, but also helps to understand single facts and actions of individuals. 


\section{Results and Discusions}

As a framework for integration policies across Europe and a guide for EU member states, the European Union established the Common basic principles in the EU in 2004. Among other things, these principles explain that integration is meant as a "dynamic process of mutual accommodation," employment is key to integration, and that the difference in values of cultures and religions is guaranteed under the Charter of Human Rights.

"Subsequently, in 2011, the European Commission proposed the European Programme for the Integration of Third-Country Nationals, focusing on actions to increase the participation of migrants, highlighting local actions, and highlighting the challenges that need to be addressed in order to benefit from migration and multiculturalism. The agenda forms a tool for national authorities to choose measures that can help them achieve their integration goals. European Integration Forum meets twice a year and provides an opportunity for leaders to discuss integration issues and goals "

The Commission also proposed in its agenda a tripartite strategy for the integration of third-country nationals. First, the strategy encourages Member States to provide language courses for immigrants at all stages of integration; to organize civic participation courses; to develop policies to attract immigrants to the labour market; and use financial instruments for effective supporting of migrants. Second, the strategy encourages local action by addressing problems in disadvantaged urban areas; to improve multi-level collaboration between different levels of government; and providing EU financial support for local action. Third, the EU encourages the participation of countries of origin by assisting migrants in providing information such as visas and work permits, as well as language courses. The EU also encourages "circular migration" so that immigrants can apply the knowledge and experience gained at home.

"The EU has established the European Fund for the Integration of Non-EU Immigrants, with a total budget of 825 million euros for the period 2007 - 2013, to support these initiatives and to enhance the capacity of EU countries to "develop, implement, monitor and evaluate integration strategies." The Fund has also established programmes to improve diversity management, intercultural learning and dialogue, as well as tools for sharing information and discussing best practices among countries" (Communication from the Commission to the European Parliament, the European Economic and Social Committee, and the Committee of the Regions, 2011) "Since 2013, the European Commission has proposed a budget of 10.9 billion euros for the period 2014-2020, which will also focus on the enforcement of law and order, the management of the EU 's external borders and the development of new technology systems such as the future entry and exit system and the Registered Traveller programme" (Funding Home Affairs Beyond, 2013).

Germany has developed its own integration system, with guidance on integration from the European Commission, including in the areas of education, employment and language. Germany continues to struggle with a fairly open form of immigration and the need to attract talent in a globalized world; With the concern of many Germans about the short- and long-term social consequences of migration flows to the country. Germany's history with gastarbeiters, its many minorities and the unfolding discussions over the past decade about citizenship and integration require special attention.

Despite the rich experience of post-war Germany in accepting asylum seekers and preventing the development of ethnically confined territories, the so-called ghetto, for decades Germany, like many EU countries, has paid only minimal attention to formal integration. This was partly due to the wrong belief that most of the gastarbeiters only worked on a temporary basis. "However, the emphasis has increased dramatically in recent years, and the German Government has taken a number of positive steps to involve migrants more fully in the wider structure of German society" (Bulent, 2002).

In particular, the issue of citizenship in Germany is inextricably linked to integration efforts. "For 150 years, nationality laws in Germany were based on jus sanguinis and jus soli" 
blood rights "and" soil law" (Migration and Integration: Residence law and policy on migration and integration in Germany, 2011). One parent must be German by birth regardless of where the child is born. Second and third generation residents born in Germany had minimal prospects for naturalization. In 1998, a coalition of Social Democrats and Greens attempted to add birthplacebased citizenship to this, which was partly a gesture for the Turkish community, whose members were not allowed to become German citizens. These changes were incorporated into the revised German Nationality Act, adopted in 1999 and which came into force in 2000, which henceforth provided for the right of children of non-citizens to obtain German citizenship if one parent legally resided in Germany for at least five years.

There are also several official integration courses and programs for immigrants. As of 2005, non-German-speaking immigrants were expected to take compulsory integration courses, with a focus on language, history, culture and the rule of law. "In 2007, the federal government, 16 Länder governments, local officials, and a number of stakeholders agreed to a new National Integration Plan. The plan and similar efforts focused on the development of the German language and values of civic activism and equality, the expansion of employment opportunities, the improvement of education and the improvement of the lives of women and girls" (EUROSTAT. Asylum applications (non-EU) in the EU-28 Member States, 2008-2018). In 2006, the German government organized the National Conference on Islam in Germany, which aimed to further incorporate the Muslims of Germany into the political process, although critics argued that the conference was not as productive because of serious differences, and that the results were pessimistic.

\section{Summary}

"Germany has faced a negative anti-immigrant reaction in recent years. For example, the belief that Islam is a threat to the core values of German society is a constant theme in the German integration debate" (Meer \& Modood, 2012). In addition, "the backlash reached the mainstream following the 2010 publication of a book by Tilo Sarrazin arguing that Muslim immigrants were unwilling and unable to integrate into German society by leading the national bestseller list" (Meer \& Modood, 2012). That same year, Chancellor Merkel said in a speech to young members of the Christian Democratic Union party that multiculturalism in Germany had failed and that it was an "illusion" that foreign workers and citizens could work together.

"In Germany, the citizenship debate became even more acute following changes to the citizenship law, which abandoned the exclusivity of" citizenship "based on origin only. Given that Germany does not allow dual citizenship for citizens of non-EU countries, the law obliges many migrant young people between the ages of 18 and 23 to choose whether to retain German citizenship or the citizenship of the country of origin of their parents" (Potemkina, 2010). Since the provisions of the 2000 law included the children of foreign nationals aged 10 and under, in 2008 those people had to make their choice on the issue of citizenship.

"However, there is a perception among many migrants that they should choose between two options: being officially German but a second-class citizen or living in Germany with another citizenship without full civil rights" (Potemkina, 2010). Thus, there was a fierce debate at the political level about whether further changes to the law should be made; Authorization for dual citizenship, in most cases among the Turkish community. Those opposed to dual citizenship for all believe it only encourages immigrants to live separate lives and support non-German individuals. Supporters believe that allowing dual citizenship allows the government and society to accept "different people."

As long as most people from migrant families feel they have not yet been fully accepted in German society, the requirement to give up their parents' citizenship to young people creates unnecessary tensions in these communities. The Turkish community expressed concern that the law was only promulgated for certain groups.

\section{Conclusion}


On the initiative of German Chancellor Angela Merkel, an emergency EU summit on migration was convened on June 24, 2018, where it was planned to find practical solutions to the problems of host countries. The Italian government expected support from the European Union not only in words, but also in practice in terms of further placement of refugees in other EU countries. Italy at this summit called for the revision of the Dublin regulation, which prescribes responsibility for migrants of the EU country that was the first on their way. This decision was necessary for the Italian government to limit the flow of refugees and migrants into the country legally. The emergency summit did not lead to any results (Ilikova, 2019).

In 2013, Germany needed to attract new immigrants in the coming decades to support the workforce because of the low birth rate among ethnic Germans. We should point out that Germany is one of the welcoming countries of Europe. Germany is a member of the Organization for Economic Co-operation and Development with the lightest immigration requirements for highly skilled workers. The immigration system is relatively open. "Germany does not impose annual limits on the number of highly skilled immigrants, the time frame for filing is short, and applicants for highly skilled positions are rarely denied. University graduates from other countries also have relatively easy access to employment in Germany. On the other hand, the outlook for long-term labour migration is rather pessimistic compared to other countries" (Labour Migration: Germany is Open to graduates, but Immigration is Difficult for Medium-Skilled Workers, 2013). Among the challenges, which Germany is facing with is that German employers rarely hire workers from outside Germany, partly because of the mediocre reputation and lack of transparency of the German application system. Language skills are also an obstacle to many immigrants.

Some barriers are difficult to overcoming, particularly because of right-wing extremist sentiments against minorities in different parts of the country. There are other areas that are under the control of Germany 's government. "Germany has taken positive steps in recent years to produce additional conditions for people arriving in the country, including the creation of a" Make it in Germany "website designed to help immigrants navigate the complex German system, and a new welcome kit containing useful information materials" (Fraczek, 2013). According to 2011 data, Germany became a leader in attracting foreign workers; besides foreign students find work more often after graduation in Germany (Jimenez, 2011).

\section{Acknowledgements}

The work is performed according to the Russian Government Program of Competitive Growth of Kazan Federal University.

\section{References}

Bulent, K. (2002). The Changing Face of Europe - Population Flows in the 20th Century. Council of Europe Publishing. February. Printed at the Council of Europe. p. 20.

Hierro, M. (2013). Latin American Migration to Spain: Main Reasons and Future Perspectives. International Organization for Migration. 18 March 2013. p. 7.

Novotný, V. (2015). Politics of Identity in Focus: What Next after Multiculturalism, Wilfried Martens Centre for European Studies, Brussels, 10-16.

Archick, K., Belkin, P., Blanchard, C.M., Ek, C., \& Mix, D.E. (2012). Muslims in Europe: Promoting Integration and Countering Extremism. New York: Nova Science Publishers. p. 6.

Migration and Integration: Residence law and policy on migration and integration in Germany (2011). German Federal Ministry of the Interior. - October 2011. p. 13.

Nesterova, A.A. (2012). Mobil'nost' rabochej sily v Evropejskom soyuze. Zhurnal mezhdunarodnogo prava i mezhdunarodnyh otnoshenij, 4(12) (In Russ).

EU Actions to Make Integration Work. (2016). European Union: European Commission.URL:http://ec.europa.eu/ewsi/en/EU_actions_integration.cfm (accessed: 20.06.19).

Communication from the Commission to the European Parliament, the European Economic and Social Committee, and the Committee of the Regions. European Agenda for the 
Integration of Third Country Nationals. (2011). European Union: European Commission. - July, p. 10.

Funding Home Affairs Beyond (2013). European Union: European Commission, 11-17.

EUROSTAT. Asylum applications (non-EU) in the EU-28 Member States, 2008-2018. URL:https://ec.europa.eu/eurostat/statistics-explained/index.php/Asylum_statistics (accessed: 17.05.19)

Meer, N., \& Modood, T. (2012). The Multicultural States. We're In. Edinburgh: University Press, p. 71.

Connolly, K. (2010). Bundesbank executive provokes race outcry with book. The Guardian. 30 August 2010. - URL: https://www.theguardian.com/world/2010/aug/30/bundesbankexecutive-book-race-row (accessed: 27.02.19)

Potemkina, O.Y. (2010). Evropejskij Soyuz v bor'be s nelegal'nymi immigracionnymi potokami: novye tendencii. Vsya Evropa, 5, 15-28 (In Russ.).

Labour Migration: Germany is Open to graduates, but Immigration is Difficult for Medium-Skilled Workers (2013). Organisation for Economic Co-operation and Development. - 4 Jan. $2013 . \quad$ - URL: http://www.oecd.org/newsroom/labour-migrationgermanyisopentograduatesbutimmigrationisdifficultformedium-skilledworkers.htm (accessed: 27.02.19)

Ilikova, L.E. (2019). The Five Star Movement: From a Blog to Italian Government. Contemporary Europe-sovremennaya Evropa, 4, 129-139.

Fraczek, J. (2013). Germany Tries Warmer Welcome for Immigrants. Deutsche Welle. URL: https://www.dw.com/en/germany-tries-warmer-welcome-for-immigrants/a-16713149 (accessed: 27.05.19).

Jimenez, T.R. (2011). Immigrants in the United States: How Well Are They Integrating into Society?. Migration Policy Institute, 5-6. 